\title{
Protoconch Enlargement in Western Atlantic Turritelline Gastropod Species Following the Closure of the Central American Seaway
}

\author{
Stephanie Sang \\ Cornell University \\ Dana Suzanne Friend \\ Cornell University \\ Warren Douglas Allmon \\ Cornell University \\ Brendan Matthew Anderson \\ West Virginia Universit, bma0022@mail.wvu.edu
}

Follow this and additional works at: https://researchrepository.wvu.edu/faculty_publications

Part of the Geology Commons

\section{Digital Commons Citation}

Sang, Stephanie; Friend, Dana Suzanne; Allmon, Warren Douglas; and Anderson, Brendan Matthew, "Protoconch Enlargement in Western Atlantic Turritelline Gastropod Species Following the Closure of the Central American Seaway" (2019). Faculty \& Staff Scholarship. 2104.

https://researchrepository.wvu.edu/faculty_publications/2104

This Article is brought to you for free and open access by The Research Repository @ WVU. It has been accepted for inclusion in Faculty \& Staff Scholarship by an authorized administrator of The Research Repository @ WVU. For more information, please contact beau.smith@mail.wvu.edu. 


\title{
Protoconch enlargement in Western Atlantic turritelline gastropod species following the closure of the Central American Seaway
}

\author{
Stephanie Sang ${ }^{1,2}$ (D) | Dana Suzanne Friend ${ }^{1,2}$ | Warren Douglas Allmon ${ }^{1,2}$ | \\ Brendan Matthew Anderson ${ }^{1,2}$
}

${ }^{1}$ Department of Earth and Atmospheric Sciences, Snee Hall, Cornell University, Ithaca, New York

${ }^{2}$ Paleontological Research Institution, Ithaca, New York

Correspondence

Brendan Matthew Anderson, Department of Geology and Geography, West Virginia University, Morgantown, WV.

Email:bma0022@mail.wvu.edu

\section{Present Address}

Stephanie Sang, Department of Organismal Biology and Anatomy, University of Chicago, Chicago, Illinois

Brendan Matthew Anderson, Department of Geology and Geography, West Virginia University, Morgantown, West Virginia

Funding information

Cornell Hunter R. Rawlings III Presidential Research Scholarship; NSF Partnerships for International Research and Education Panama Canal Project (PCP-PIRE); Cornell Office of Undergraduate Biology; Cornell College of Arts and Sciences Undergraduate Research Grant; Cornell Einhorn Discovery Grant

\begin{abstract}
The closure of the late Neogene interoceanic seaways between the Western Atlantic (WA) and Tropical Eastern Pacific (TEP)-commonly referred to as the Central American Seaway-significantly decreased nutrient supply in the WA compared to the TEP. In marine invertebrates, an increase in parental investment is expected to be selectively favored in nutrient-poor marine environments as prolonged feeding in the plankton becomes less reliable. Here, we examine turritelline gastropods, which were abundant and diverse across this region during the Neogene and serve as important paleoenvironmental proxies, and test whether species exhibit decreased planktotrophy in the WA postclosure as compared to preclosure fossils and extant TEP species. We also test for differences in degree of planktotrophy in extant sister species pairs. Degree of planktotrophy was inferred by measuring the size of protoconchs, the species' larval shell that represents egg size. Protoconch size was compared between extant postclosure WA and TEP species and preclosure fossil species. To compare extant sister species, we reconstructed the phylogeny of available WA and TEP species using one nuclear ( $\mathrm{H} 3$ ) and three mitochondrial markers (12S, 16S, and COI). Compared to the preclosure fossils, protoconch size increased in WA species but remained the same in the TEP species. In the two extant sister species pairs recovered in the phylogenetic analysis, the WA species are inferred to be nonplanktotrophic while the TEP species are planktotrophic. This suggests that decreased nutrient availability and primary productivity in the WA may have driven this change in developmental mode, and was the primary selective force resulting in postclosure turritelline extinctions.
\end{abstract}

\section{KEYWORDS}

extinction selectivity, larval mode, macroevolution, Miocene, molecular phylogeny, Pliocene, Turritella

This is an open access article under the terms of the Creative Commons Attribution License, which permits use, distribution and reproduction in any medium, provided the original work is properly cited.

(c) 2019 The Authors. Ecology and Evolution published by John Wiley \& Sons Ltd. 


\section{1 | INTRODUCTION}

The closure of the interoceanic seaways between the Tropical Eastern Pacific (TEP) and the Western Atlantic (WA)-commonly referred to as the Central American Seaway (O'Dea et al., 2018,2016)-in the late Neogene resulted in significant changes to the abiotic and biotic oceanographic conditions in the WA. Interoceanic connections for shallow-water organisms, such as turritelline gastropods, persisted throughout the early stages of closure (Allmon, 2001; Beu, 2001; Coppard \& Lessios, 2017; Hendy, 2013; Jackson \& O'Dea, 2013; Lessios, 2008; Marko \& Moran, 2002,2009; O'Dea et al., 2016), with communication of TEP upwelling waters to the WA through the middle Miocene (Anderson, Hendy, Johnson, \& Allmon, 2017), shallowing around $8 \mathrm{Ma}$, but returning to deeper water communication by $6 \mathrm{Ma}$ (Collins, 1996; Coates, Aubry, Berggren, Collins, \& Kunk, 2003; Coates, Collins, Aubry, \& Berggren, 2004; Leigh, O'Dea, $\&$ Vermeij, 2014; O'Dea et al., 2016). Final closure occurred between 3.5 and 2.7 Ma (Coppard \& Lessios, 2017; Cronin \& Dowsett, 1996; Jackson \& O'Dea, 2013; Leigh et al., 2014; Molnar, 2008; O'Dea et al., 2018,2016).

As the interoceanic seaways closed, the WA experienced substantially reduced productivity (Allmon, 2001; Collins, 1996; O'Dea \& Collins, 2013; Todd et al., 2002), due to some combination of reduced communication of Pacific upwelling waters (Anderson et al., 2017; Leigh et al., 2014; O'Dea et al., 2007), changes in circulation which may have reduced local upwelling (Allmon, 2001; Allmon, Emslie, Jones, \& Morgan, 1996; Allmon, Rosenberg, Portell, \& Schindler, 1996; Hays, Pisias, \& Roelofs, 1989; Jackson \& Budd, 1996; Jackson \& O'Dea, 2013; Leigh et al., 2014; Lessios, 2008; Maier-Reimer, Mikolajewicz, \& Crowley, 1990; O'Dea et al., 2016; Todd et al., 2002), and possible decreased riverine nutrient input $\sim 2.5$ Ma (Aguilera et al., 2013; Pérez-Consuegra et al., 2018). In response to decreased productivity, the biological community in the WA changed concurrently with this environmental change through shifts in the composition of benthic communities and life histories of benthic species (Jackson \& Johnson, 2000; O'Dea et al., 2007; Todd et al., 2002), demonstrating the dramatic change in nutrient regime (Allmon, 1992,2001; Jackson \& Johnson, 2000; Leigh et al., 2014; O'Dea et al., 2007,2016; Smith \& Jackson, 2009; Todd et al., 2002). These ecological shifts were later ( 1-2 Myr) accompanied by pulses of extinction, possibly due to declining population sizes (O'Dea et al., 2007; O'Dea et al., 2016).

In marine gastropods, larval mode is a life-history trait that is predicted to have changed in response to declining WA nutrient productivity. Larval mode can generally be divided into two types based on whether larvae feed in the plankton: planktotrophic (feeding) or nonplanktotrophic (nonfeeding) (Jablonski \& Lutz, 1980,1983; Thorson, 1950). These reproductive strategies result from tradeoffs between larval mortality and parental investment. Predation (Hickman, 2001) and starvation result in high larval mortality rates (as high as 99\%) (Mileikovsky, 1971; Thorson, 1950). Larger, yolkrich eggs will reduce larval mortality, but higher parental investment results in fewer eggs being produced (Crisp \& Spencer Davies,
1976; Jablonski \& Lutz, 1980; Marshall, McAlister, \& Retizel, 2018; Scheltema, 1971; Strathmann, 1978; Vance, 1973).

The closure of the Central American interoceanic seaways and associated changes in nutrient conditions in the WA allows us the opportunity to directly test the relationship between decreased ambient nutrient supply and nutrient apportionment in gastropod eggs. A decrease in marine nutrient supply is expected to result in decreased planktotrophy success and therefore favor increased parental investment (Fortunato, 2004; Jablonski \& Lutz, 1980; Lessios, 1990,2008; Marshall et al., 2018; Miura, Frankel, \& Torchin, 2011; Vance, 1973). Even if larvae still spend some time feeding in the plankton, larger offspring are better buffered against starvation and may need to spend less time in the plankton before settlement (Marshall \& Keough, 2007; Marshall et al., 2018).

We chose turritelline gastropods (Figure 1) to test our hypothesis that decreased nutrient availability selects for larger eggs. Turritelline gastropods are a highly diverse clade with as many as 150 valid Recent and ca. 800 valid fossil species and are often among the most abundant gastropods where they occur (Allmon, 1988,2011). Their typical affinity for fully marine environments coupled with their low trophic level has also led them to be important paleoclimate and environmental proxies (Allmon, 2011; Anderson et al., 2017; Jones \& Allmon, 1995). Prior to the closure of the tropical American interoceanic seaways, turritellines were common and diverse in the WA (Allmon, 1992,2001; Anderson et al., 2017; Todd et al., 2002). Today, turritellines are rare in the modern WA and are represented by only three species: T. exoleta (Linnaeus, 1758), T. variegata (Linnaeus, 1758), and T. acropora (Dall, 1889). In contrast, the Late Miocene and Pliocene WA each contained over 25 species (Allmon, 1992; Allmon, Rosenberg, et al., 1996) and the Recent TEP is home to at least eight species: T. anactor (Berry, 1957), T. banksii (Reeve, 1849), T. clarionensis (Hertlein \& Strong, 2011), T. gonostoma (Valenciennes, 1832), T. leucostoma (Valenciennes, 1832), T. nodulosa (King \& Broderip, 1832), T. radula (Kiener, 1838), and T. rubescens (Reeve, 1849). These surviving WA lineages represent potential sister lineages (sometimes referred to as "geminate species"; Jordan, 1908; Marko \& Moran, 2009; Miura et al., 2011) evolving separately for 3-5 Ma and under strikingly different nutrient regimes for at least 2 Ma (Todd et al., 2002; Todd \& Johnson, 2013). The extinction of numerous WA turritelline species postclosure implies strong selective pressures on the WA species (Allmon, 1992).

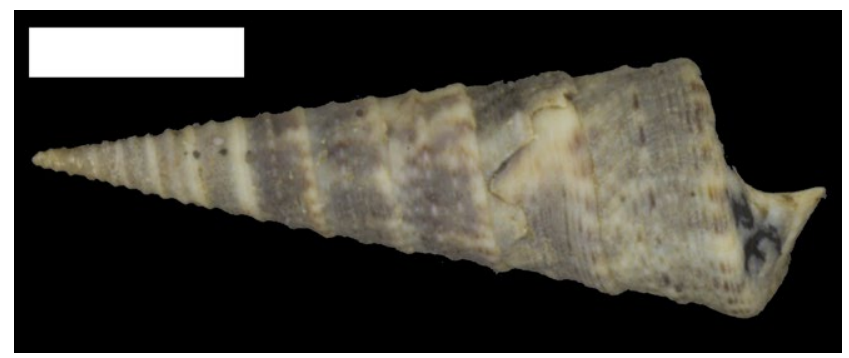

FIG URE 1 Turritella banksii (PRI 68087), a postclosure turritelline from the Tropical Eastern Pacific. Scale bar $=1 \mathrm{~cm}$ 
TABLE 1 Taxa examined in this study

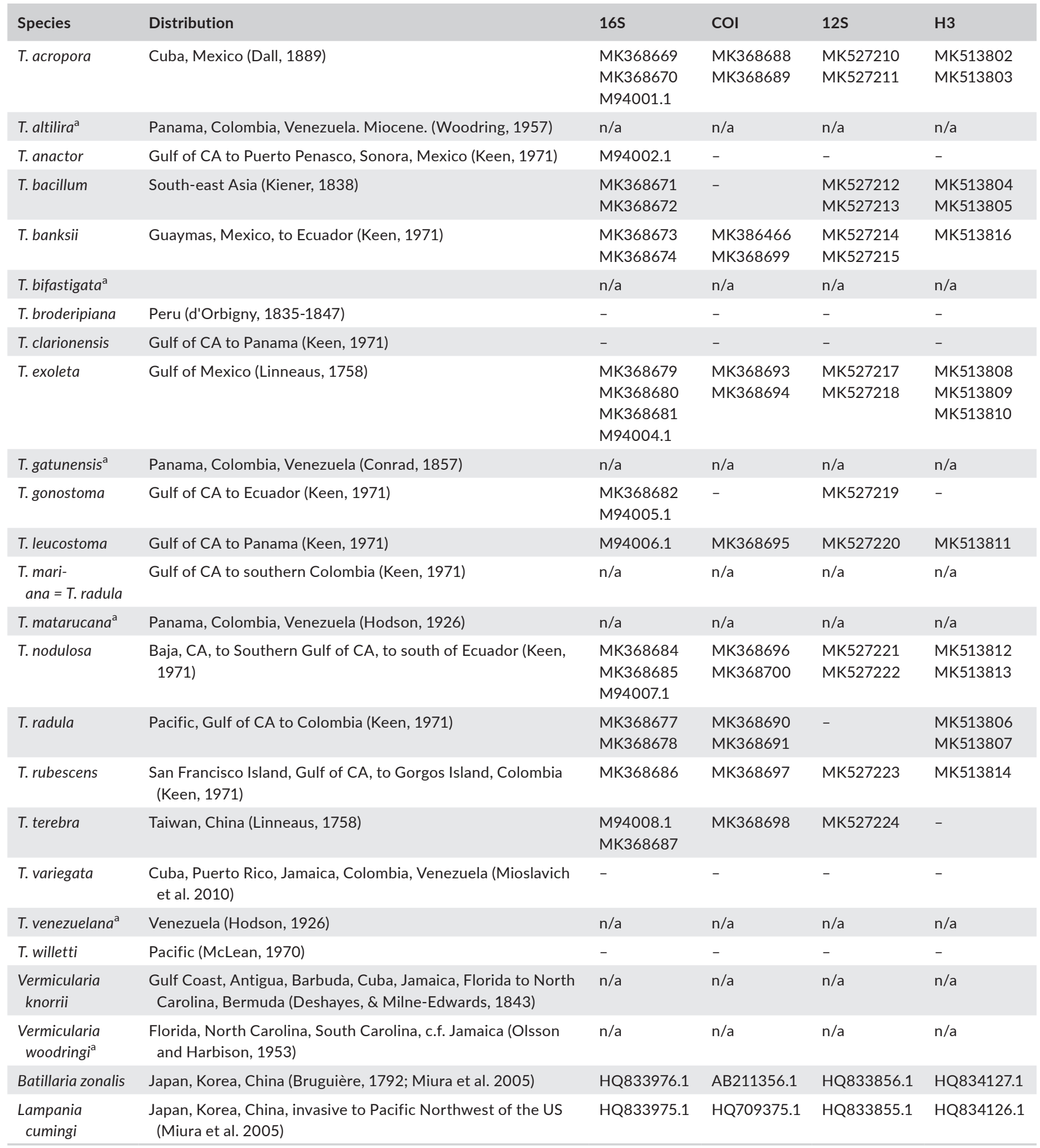

Note. GenBank accession numbers for sequence data listed for each marker examined.

${ }^{a}$ Denotes extinct taxa.

Inferences can be made about the larval mode of fossil and extant gastropods based on observations of the protoconch (larval shell), which is sometimes retained at the apex of the adult shell (Fortunato, 2002,2004; Jablonski \& Lutz, 1983; Jackson \& Fortunato, 1996; Lima \& Lutz, 1990; Shuto, 1974; Thorson, 1950;
Vendetti, 2007). Large, paucispiral protoconchs are presumed to be formed by larval gastropods that have spent little or no time in the plankton, and narrow, multispiral protoconchs are thought to indicate prolonged planktonic phases. Shuto (1974) used living taxa of known larval mode to describe what quantitative values 
in protoconch maximum diameter and number of volutions are associated with each mode. Although egg size, as inferred from protoconch size, is not the sole form of increased parental investment (e.g., it does not capture different nutritional content in an egg), it is a useful approximation (Marshall et al., 2018; Moran \& McAlister, 2009).

It is expected that decreased nutrient availability in the plankton would result in selection for greater nutrient apportionment (larger eggs) which should be reflected in increased sizes for protoconchs in postclosure WA species. We test these hypotheses by comparing (a) turritelline protoconch size in the postclosure WA with both modern TEP protoconch sizes and preclosure fossil protoconch sizes, and (b) comparing protoconch size changes in extant sister species pairs by generating a robust molecular phylogeny of TEP and WA turritellines based on $\mathrm{H} 3, \mathrm{COI}, 16 \mathrm{~S}$, and $12 \mathrm{~S}$ sequence data.

\section{2 | MATERIALS AND METHODS}

\section{1 | Taxon sampling}

We sampled seven of the eight species of Turritella in the TEP and two of the four species in the WA (Table 1). Protoconch preservation can be rare, even in live-collected individuals from modern species. Preclosure WA fossil species examined are those described from the late Miocene of Panama and the late Oligocene of Venezuela. Although the only protoconch sampled for the extant species Vermicularia knorrii (Deshayes, 1843) was from a Pleistocene specimen, the specimen is considered part of the postclosure WA fauna. Batillaria zonalis (Bruguière, 1792) and Lampania cumingi (Gray, 1847) (Batillariidae) were selected as out-groups due to the consistent placement of Batillaridae as sister to Turritellidae (Strong et al. 2011).

Wet specimens were obtained from the collections of the Florida Museum of Natural History (FLMNH) and Paleontological Research Institution (PRI). Specimens of T. banksii were collected at Bique, Panama. Protoconch data were obtained from specimens in the collections of the FLMNH, PRI, and Academy of Natural Sciences (ANSP), as well as from material collected in April 2014 at various localities in Colón, Panama. Specimens newly collected for this analysis are stored at the PRI, and DNA elutions are archived at the
Cornell Lab of Ornithology. In molecular analyses, data sources are identified as UF = University of Florida, FLMNH collection, $\mathrm{S}=$ this study collected, and $L=$ Lieberman, Allmon, and Eldredge (1993) from GenBank data.

\section{2 | DNA extraction, sequencing, and alignment}

Genomic DNA was extracted using the Qiagen DNeasy Kit from about $100 \mathrm{mg}$ of tissue, following the manufacturer's protocol. We chose the mitochondrial 16S, 12S, cytochrome c oxidase subunit I (COI), and nuclear histone $\mathrm{H} 3$ regions for sequencing because $16 \mathrm{~S}$ fragments are available from a subset of our species (Lieberman et al., 1993), and because there exist gastropod-specific primers for these genes (Miura, Torchin, Kuris, Hechinger, \& Chiba, 2006; Simon, Franke, \& Martin, 1991; Zou, Li, \& Kong, 2011) (Table 2). The PCR mixture included $0.002 \mu \mathrm{g} / \mu \mathrm{l}$ bovine serum albumen to improve PCR yields (Farell \& Alexandre, 2012; Woide, Zink, \& Thalhammer, 2010). Each reaction ran for 35 cycles of $95^{\circ} \mathrm{C}$ for $4.5 \mathrm{~min}, 95^{\circ} \mathrm{C}$ for $1 \mathrm{~min}$, between 54 and $64^{\circ} \mathrm{C}$ for $1 \mathrm{~min}$ (the optimal annealing temperature varied), $72^{\circ} \mathrm{C}$ for $1: 20 \mathrm{~min}$, and $72^{\circ} \mathrm{C}$ for $4.5 \mathrm{~min}$. In preparation for sequencing, all $\mathrm{PCR}$ products were treated with exonuclease (10 $\mathrm{U} /$ $\mu \mathrm{l})$ and shrimp alkaline phosphatase $(1 \mathrm{U} / \mu \mathrm{l})$ at $37^{\circ} \mathrm{C}$ for $30 \mathrm{~min}$ and then at $90^{\circ} \mathrm{C}$ for $10 \mathrm{~min}$. Sanger sequencing took place at the Cornell Biotechnology Resource Center. Newly sequenced molecular data were then aligned with previously published GenBank data (Table 1). Sequences were aligned using MAFFT-L-INS-i v. 7 (Katoh \& Standley, 2013) and checked with Mesquite v. 3.0.3 (Maddison \& Maddison, 2015) by eye. Genes were concatenated with SequenceMatrix v. 1.7.8 (Vaidya, Lohman, \& Meier, 2011). Mesquite was then used to annotate codon positions.

\section{3 | Phylogenetic analysis}

Phylogenetic analysis of molecular characters was performed with parsimony, maximum-likelihood, and Bayesian methods. Parsimony analysis was run using PAUP* v. 4.0a141 (Swofford, 2002). Out of 2,328 total characters, 558 were parsimony-informative. Overall base pair frequencies were calculated as $A=0.28, T=0.30, C=0.21$, $\mathrm{G}=0.21$. A heuristic search was set with random stepwise addition

TABLE 2 Primer pairs for each gene region

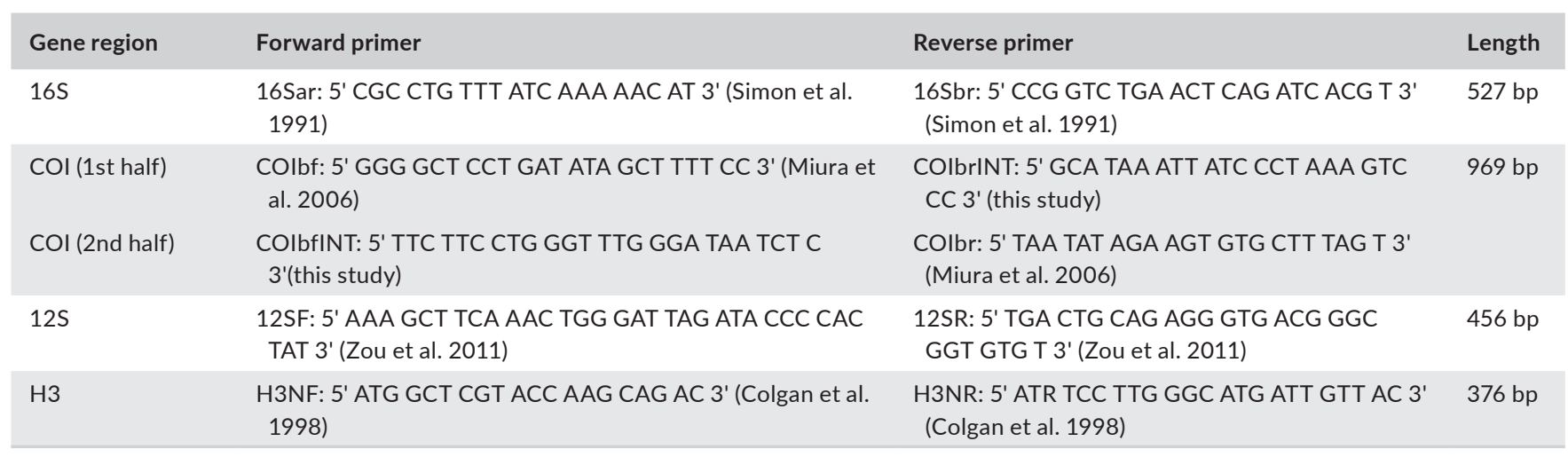


(10,000 repetitions) and a TBR swapping algorithm. All other settings were left as default.

For maximum-likelihood analysis, sequences were partitioned by codon position in each gene and run under a GTRCAT (default setting) model with joint branch length optimization using RAxML 8.0.9 on the Cyberinfrastructure for Phylogenetic Research (CIPRES) platform (Miller, Pfeiffer, \& Schwartz, 2010) to calculate the ML tree and nonparametric bootstrap node support. The resulting tree was visualized on FigTree v. 1.4.2 (Rambaut, 2016).

For Bayesian analysis, sequences were entered into MrBayes v. 3.4.2 (Ronquist \& Huelsenbeck, 2003) on the CIPRES system. Each gene was partitioned by codon position. The partitions were assigned a model of best-fit in PartitionFinder v. 1.1.1 (Lanfear, Calcott, Ho, \& Guindon, 2012) according to the Akaike information criterion (Table S1). In MrBayes, two runs were conducted with four chains each for 10 million generations. The first $25 \%$ of results were discarded as burnin. All other settings were left as default. Log files were combined and checked with Tracer v. 1.6 (Rambaut \& Suchard, 2014). A statistical summary of the ML and Bayesian analyses is presented in Table S2.

\section{4 | Protoconch measurements}

Specimens with intact protoconchs were almost entirely found on juveniles less than one centimeter in length. Protoconchs are often abraded away in turritellines, even during the life of the organism (Johnson, Anderson, \& Allmon, 2017). The protoconch is composed of two parts: protoconch I, which is the embryonic shell, formed prior to hatching and is unornamented, and protoconch II which is produced prior to metamorphosis, and which may be smooth or ornamented (Jablonski \& Lutz, 1983; Robertson, 1971). Whole shells were sputter-coated with a thin layer of gold then imaged on a scanning electron microscope (JCM-6000 NeoScope Benchtop SEM) at the PRI. Venezuelan specimens from the type and figured collection of the PRI were imaged without sputter-coating. Side and top view images were taken to identify the protoconch I-protoconch II boundary, which was then marked on the top view image. We used this boundary to find the total number of volutions (full 360-degree spirals) in protoconch I. The diameter of protoconch I was measured at its widest using ImageJ v.1.45s (Schneider, Rasband, \& Eliceiri, 2012).

\subsection{Analysis of protoconch character divergence}

Statistical comparisons were made among protoconch data obtained from preclosure fossil, postclosure Atlantic, and postclosure Pacific specimens in Past3 (Hammer, Harper, \& Ryan, 2001). Both protoconch maximum diameter and diameter/volutions ratio were compared. Tukey's $Q$ was calculated to make comparisons among means for all three data sets simultaneously, with significance estimated according to the method of Copenhaver and Holland (1988). The Mann-Whitney $U$ test was applied to determine whether the samples were likely to be drawn from the same distributions.

Continuous character mapping of protoconch diameters on the molecular phylogeny was achieved using the "contMap" function in the "phytools" (Revell, 2012) package for R. The "contMap" function estimates character states at internal nodes using ML methods (function "anc.ML"). From the Bayesian tree, multiple individuals for each species were collapsed into one tip using the "delete subelements" function in TreeGraph2 (v. 2.14.0-771) (Stöver \& Müller, 2010) to create a consolidated backbone. The average protoconch diameter for each species was then mapped onto each tip.

\section{3 | RESULTS}

\section{1 | Molecular phylogeny}

Two extant sister species pairs are consistently identified in the molecular trees (Figures 2-4). The first pair is T. exoleta (WA) and T. radula (TEP), which was discovered in all three methods (parsimony,
FIGURE 2 Majority rule parsimony tree (consensus of 81 trees) generated from mitochondrial and nuclear sequences. All species are from genus Turritella, except for out-groups Batillaria zonalis and Lampania cumingi. L1 = sequence from Lieberman et al. (1993); S1 or S2 = specimen collected for this study; UF1 or UF2 = specimen from FLMNH

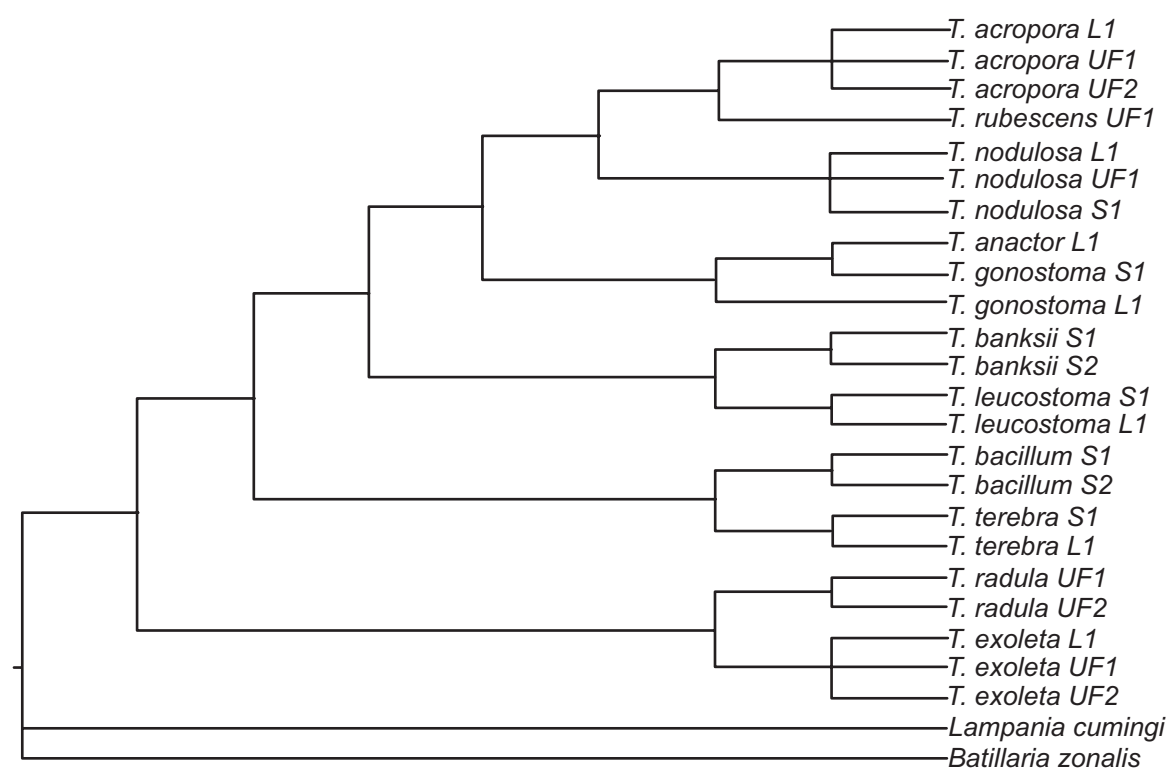




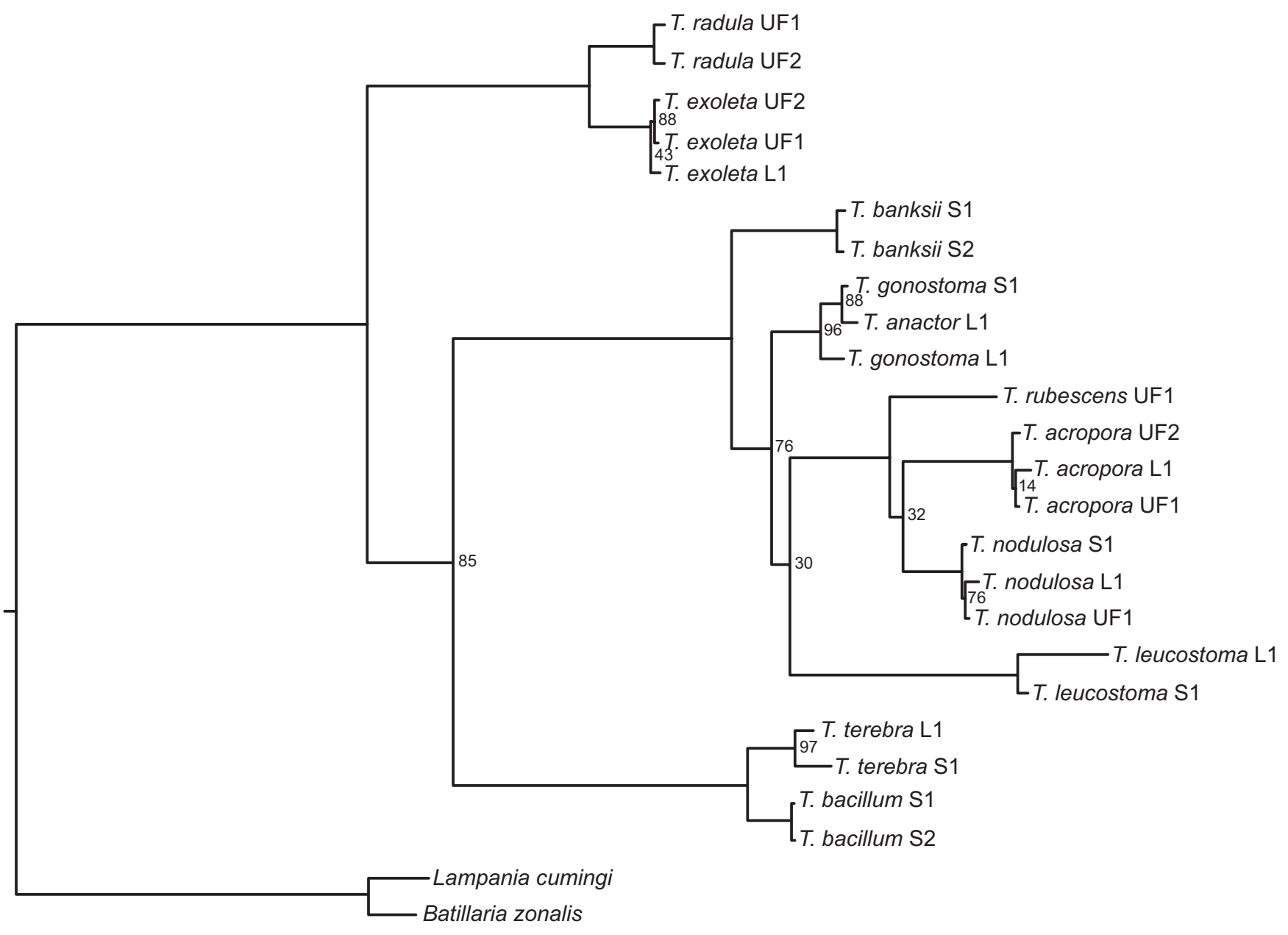

0.3

FIGURE 3 Maximum-likelihood tree generated from mitochondrial and nuclear sequences. Unless noted, bootstrap values at each node are 100. All species are from genus Turritella, except for out-groups Batillaria zonalis and Lampania cumingi. L1 = sequence from Lieberman et al. (1993); S1 or S2 = specimen collected for this study; UF1 or UF2 = specimen from FLMNH. Scale bar represented mean number of nucleotide substitutions per site

maximum-likelihood, and Bayesian). The second pair, T. acropora (WA) and T. nodulosa (TEP), is identified in both the maximum-likelihood and Bayesian results (Figures 3 and 4), but exists as a "sister species cluster" with T. rubescens under the parsimony method (Figure 2).

All methods find three major clades within these turritellines: (a) T. exoleta and T. radula sister to all other taxa, (b) T. bacillum and T. terebra sister to the remaining taxa, and (c) all other species. Most of the incongruence is located within this last clade due to unstable placement of T. banksii, T. leucostoma, and T. rubescens among methodologies.

\section{2 | Protoconch size changes after closure of the Central American Seaway}

Protoconch size data were obtained for the species identified in Table 3. We found that postclosure WA turritelline species as a whole experienced significant change in both protoconch diameter (Tables 4 and 5) and in diameter/volutions (D/Vol) compared with preclosure values (Figure 5; Tables 4 and 6). No significant change was found in TEP species relative to the preclosure fossil species in maximum diameter (Table 5) or diameter/volutions ratio (Table 6). Protoconch diameters (Tables 5) and D/Vol (Table 6) measurements differ significantly between Recent WA and Recent TEP species.

The distribution of these measurements is shown in Figure 6, where all observed protoconch diameters are plotted against D/Vol. Distributions of fossil and WA protoconch characteristics occupy different areas in component space, whereas the distribution of TEP protoconch characteristics is an expansion of the fossil distribution.

\section{4 | DISCUSSION}

\section{1 | Evolution of developmental mode in Central American Isthmus turritellines}

We find evidence of increased nonplanktotrophy in WA species and conclude that this was likely a response to decreased nutrient availability in the WA after the closure of the interoceanic seaways. The 


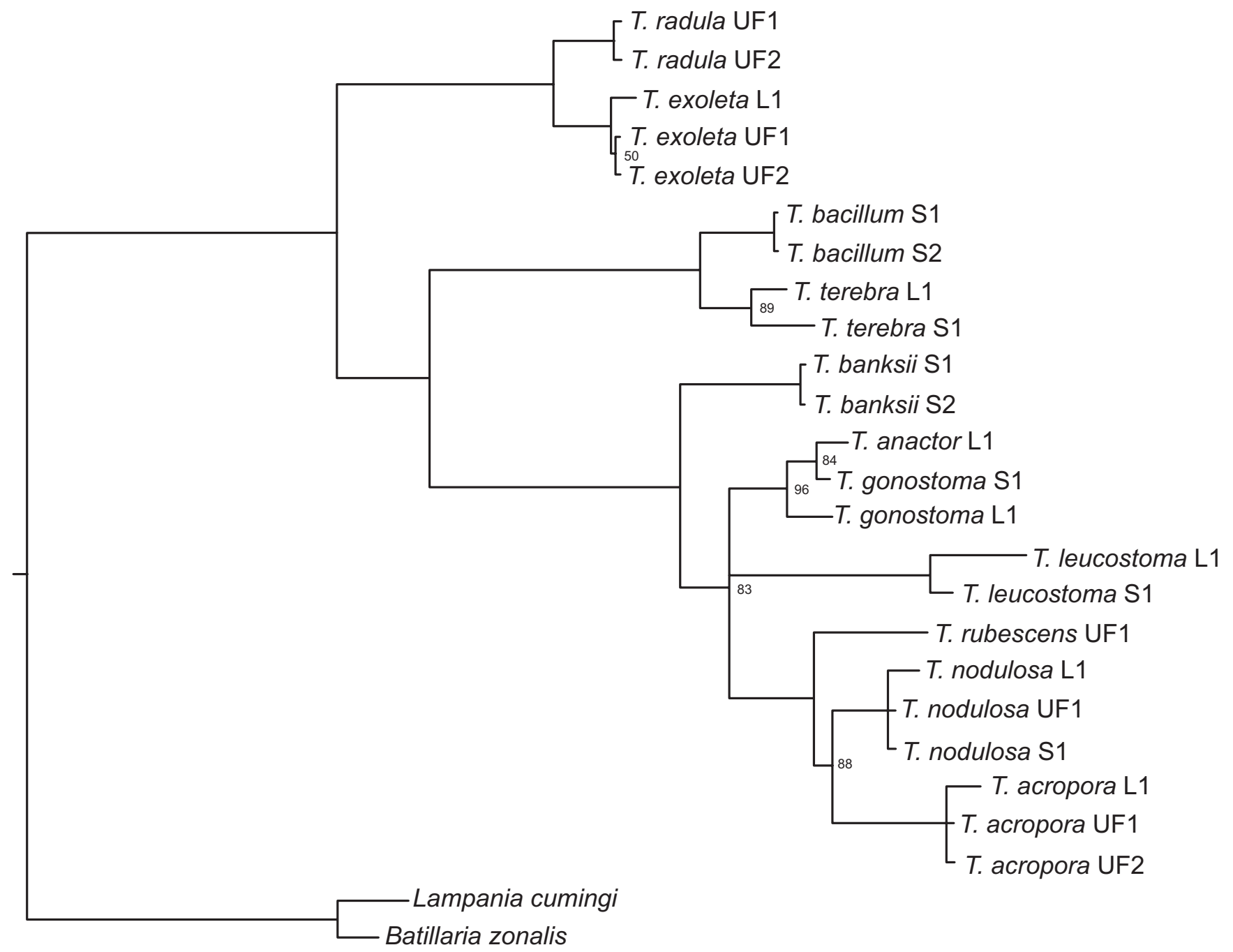

0.1

FIGURE 4 Bayesian tree generated from nuclear and mitochondrial sequence data. Posterior probabilities at nodes are 100 unless noted. All species are from genus Turritella, except for out-groups Batillaria zonalis and Lampania cumingi. L1 = sequence from Lieberman et al. (1993); S1 or S2 = specimen collected for this study; UF1 or UF2 = specimen from FLMNH

similarity of preclosure protoconch diameters to postclosure TEP protoconch diameters affirms that the observed difference in the modern populations is not due to a decline in mean protoconch size in the Pacific. The minimum protoconch size observed $(157.5 \mu \mathrm{m})$ was from a TEP species and is nearly half of the minimum observed size for WA species (316.2 $\mu \mathrm{m}$ ). Maximum observed protoconch sizes were similar between modern WA $(475 \mu \mathrm{m})$ and TEP $(470 \mu \mathrm{m})$ species. This indicates that selection against small protoconch size was the likely driver of this change. Because we show that the WA species examined are sister to EP species in our molecular phylogeny, we regard the evolution of increased nonplanktotrophy as separate, independent occurrences within each lineage. The observation that these surviving lineages have independently increased protoconch sizes relative to preclosure along with the observation of similar changes in other taxa (Fortunato, 2004; Jackson, Jung, \& Fortunato, 1996; Lessios, 1990; Miura et al., 2011; Moran, 2004; Wehrtmann \&
Albornoz, 2002) strongly supports the adaptive significance of these changes.

This phylogeny updates the only existing molecular phylogeny of turritellines that was based only on partial mitochondrial $16 \mathrm{~S}$ sequences (Lieberman et al., 1993). We recover a different topology than presented in Lieberman et al. (1993) due to the additional genetic data; we double the read length for the $16 \mathrm{~S}$ sequences and add in three other genes to our dataset. In that previous study, which included many of the same species, turritellines were used as a case study to investigate whether there were signals of species selection favoring increased diversification of nonplanktotrophic species. This hypothesis was motivated by the observation that nonplanktotrophic turritelline species outnumber planktotrophic species approximately 3:1 in the Neogene Gulf Coastal Plain, and worldwide today nonplanktotrophic species are twice as common as planktotrophic species (Allmon, 1992). Larval mode has been 
TAB LE 3 Turritelline protoconch diameters and diameter/volutions ratios observed in this study

\begin{tabular}{|c|c|c|c|c|}
\hline Species & Cohort & Age & Diameter $(\mu \mathrm{m})$ & Diameter/volutions \\
\hline T. acropora & Postclosure Atlantic & Recent & 420 & 2.44 \\
\hline T. altilira & Preclosure fossil & Miocene & 272 & 2.18 \\
\hline T. altilira & Preclosure fossil & Miocene & 300 & 1.23 \\
\hline T. banksii & Postclosure Pacific & Recent & 285.57 & 2.72 \\
\hline T. broderipiana & Postclosure Pacific & Recent & 426.5 & 3.23 \\
\hline T. exoleta & Postclosure Atlantic & Recent & 350 & 3.50 \\
\hline T. exoleta & Postclosure Atlantic & Recent & 373.49 & 3.29 \\
\hline T. gonostoma & Postclosure Pacific & Recent & 470 & 2.35 \\
\hline T. leucostoma & Postclosure Pacific & Recent & 274.19 & 2.49 \\
\hline T. leucostoma & Postclosure Pacific & Recent & 269.66 & 1.80 \\
\hline T. leucostoma & Postclosure Pacific & Recent & 230 & 1.50 \\
\hline T.radula ("mariana") & Postclosure Pacific & Recent & 203.53 & 1.36 \\
\hline T. nodulosa & Postclosure Pacific & Recent & 228.15 & 1.95 \\
\hline T. nodulosa & Postclosure Pacific & Recent & 299.662 & 1.65 \\
\hline T. nodulosa & Postclosure Pacific & Recent & 294.197 & 1.56 \\
\hline T. nodulosa & Postclosure Pacific & Recent & 300 & 1.50 \\
\hline T. wiilletti & Postclosure Pacific & Recent & 346.6 & 2.84 \\
\hline T. exoleta & Postclosure Atlantic & Recent & 320.62 & 3.56 \\
\hline T. variegata & Postclosure Atlantic & Recent & 316.17 & 2.53 \\
\hline T. venezuelana & Preclosure fossil & Late Oligocene & 230 & 1.73 \\
\hline T. gilbertharrisi & Preclosure fossil & Late Oligocene & 240 & 1.92 \\
\hline Vermicularia knorrii & Postclosure Atlantic & Pleistocene & 320 & 2.09 \\
\hline V. woodringi & Preclosure fossil & Miocene & 280 & 1.87 \\
\hline
\end{tabular}

considered to be a particularly important factor for macroevolution and speciation rates in gastropods (Crampton, Cooper, Beu, Foote, \& Marshall, 2010; Hansen, 1978; Jablonski, 1987; Jablonski \& Valentine, 1990; Krug et al., 2015; Parsons, 1997; Scheltema, 1971,1978). Planktotrophic larvae tend to spend more time in the plankton and therefore generally have higher dispersal potential, wider geographic ranges, and lower rates of isolate formation and consequent speciation. Nonplanktotrophic species, which spend little or no time in the plankton, generally have decreased dispersal, narrower ranges, and consequently, higher theoretical potential for allopatric speciation and extinction (Bhaud, 1993;
Jablonski \& Lutz, 1980,1983; Jackson et al., 1996; Vermeij, 1982). While the Lieberman et al. (1993) topology is markedly different from the ones shown in this paper, both studies indicate that the ancestral turritelline condition was planktotrophy. This conclusion is further strengthened for the observed taxa by our finding that all preclosure forms in the Central American Isthmus region had protoconch sizes indicative of planktotrophy. Additionally, both this paper and Lieberman et al. (1993) find that nonplanktotrophy arose within single species instead of at the base of nonplanktotrophic clades, and so likely did not drive increased speciation in the sampled taxa. 
TABLE 4 Comparison of turritelline protoconch diameter among preclosure (late Oligocene-middle Miocene) fossil, postclosure (Pleistocene-Recent) Atlantic, and postclosure Pacific species

TABLE 5 Statistical comparisons of protoconch diameter among preclosure fossil, postclosure Atlantic, and postclosure Pacific turritellines

\begin{tabular}{|llll} 
& Preclosure fossil & Postclosure Atlantic & Postclosure Pacific \\
\hline$N$ (protoconchs) & 8 & 7 & 20 \\
\hline $\begin{array}{l}\text { (species } \\
\text { represented) }\end{array}$ & 5 & 4 & 10 \\
\hline Min $(\mu \mathrm{m})$ & 230 & 316.2 & 157.5 \\
\hline Max $(\mu \mathrm{m})$ & 300 & 475 & 470 \\
\hline Mean $(\mu \mathrm{m})$ & 271.3 & 367.9 & 289.2 \\
\hline$S E$ & 8.5 & 22.8 & 19.2 \\
\hline Variance & 583.6 & 3623.8 & 7404.5 \\
\hline SD & 24 & 60.2 & 86.0 \\
\hline Median & 278 & 350 & 289.9 \\
\hline
\end{tabular}

\begin{tabular}{lll} 
Protoconch diameter & Tukey's Q & Mann-Whitney U \\
\hline Preclosure fossil versus Postclosure Atlantic & $4.114 ; p=0.01758$ & $0 ; p=0.004$ \\
\hline Preclosure fossil versus Recent Pacific & $0.7605 ; p=0.8534$ & $69 ; p=1$ \\
\hline Pacific versus Postclosure Atlantic & $3.354 ; p=0.06041$ & $26 ; p=0.048$ \\
\hline
\end{tabular}

Note. Statistically significant $p$ values in bold.
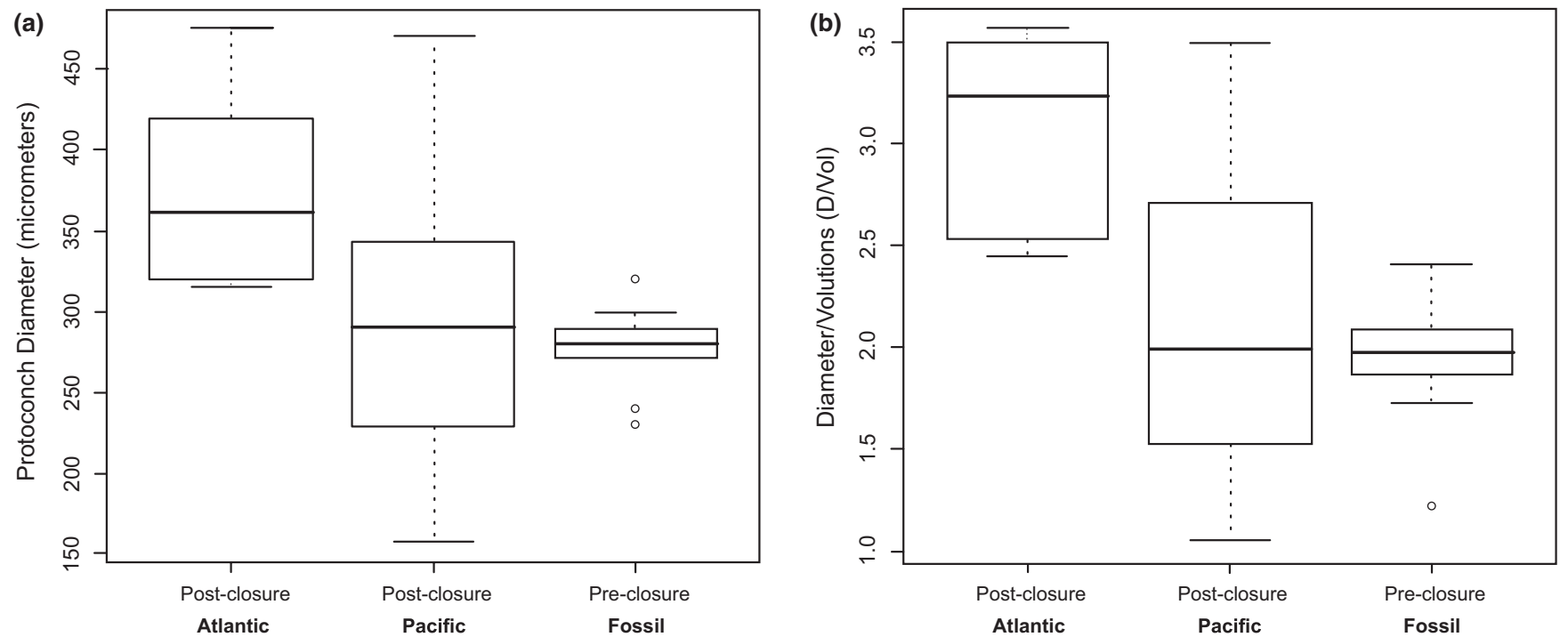

FIGURE 5 Postclosure Atlantic species are nonplanktotrophic compared to planktotrophic postclosure Pacific and preclosure fossil species. Quartile plots of (a) protoconch diameter and (b) diameter/volutions (D/Vol) ratio for postclosure Atlantic, postclosure Pacific, and preclosure fossil species

TAB LE 6 Statistical comparisons of protoconch diameter/volutions ratios among preclosure fossil, postclosure Atlantic, and postclosure Pacific turritellines

\begin{tabular}{|c|c|c|}
\hline Protoconch D/Vol & Tukey's Q & $\begin{array}{l}\text { Mann- } \\
\text { Whitney U }\end{array}$ \\
\hline $\begin{array}{l}\text { Preclosure fossil versus Postclosure } \\
\text { Atlantic }\end{array}$ & $5.145 ; p=0.002695$ & $\begin{aligned} 2 & \\
p= & 0.008386\end{aligned}$ \\
\hline Preclosure fossil versus Recent Pacific & $1.429 ; p=0.5756$ & $50 ; p=1$ \\
\hline Recent Pacific versus Postclosure Atlantic & $3.716 ; p=0.03385$ & $38 ; p=0.0204$ \\
\hline
\end{tabular}

Note. Statistically significantly values in bold.

The pattern of increased protoconch size in postclosure WA species is consistent with our hypothesis that decreased nutrient availability in the WA selected for nonplanktotrophy, and the phylogeny indicates that at least two of the three Recent WA species evolved larger protoconch sizes independently (Figure 7). Further research is, however, necessary to determine the underlying 


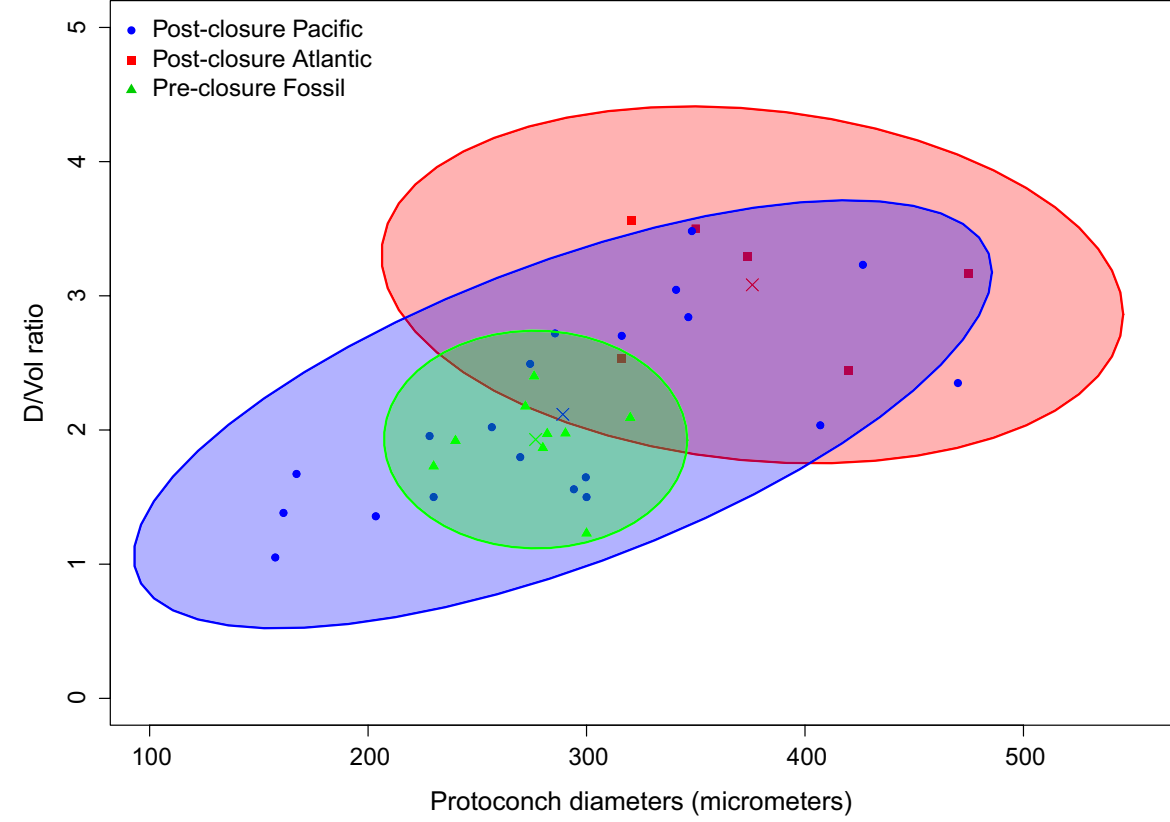

FIGURE 6 Changes in character space occupied by preclosure fossil, and postclosure Atlantic and postclosure Pacific turritelline protoconchs. 90\% confidence ellipses are shown macroevolutionary mechanisms responsible for these changes. As modern TEP turritellines exhibit a great diversity of protoconch sizes, it is possible that the modern differences are the result of either selective extinction of lineages which have small protoconchs (inferred planktotrophs, following Shuto, 1974), or selection on each lineage for larger protoconchs through time in the WA, with
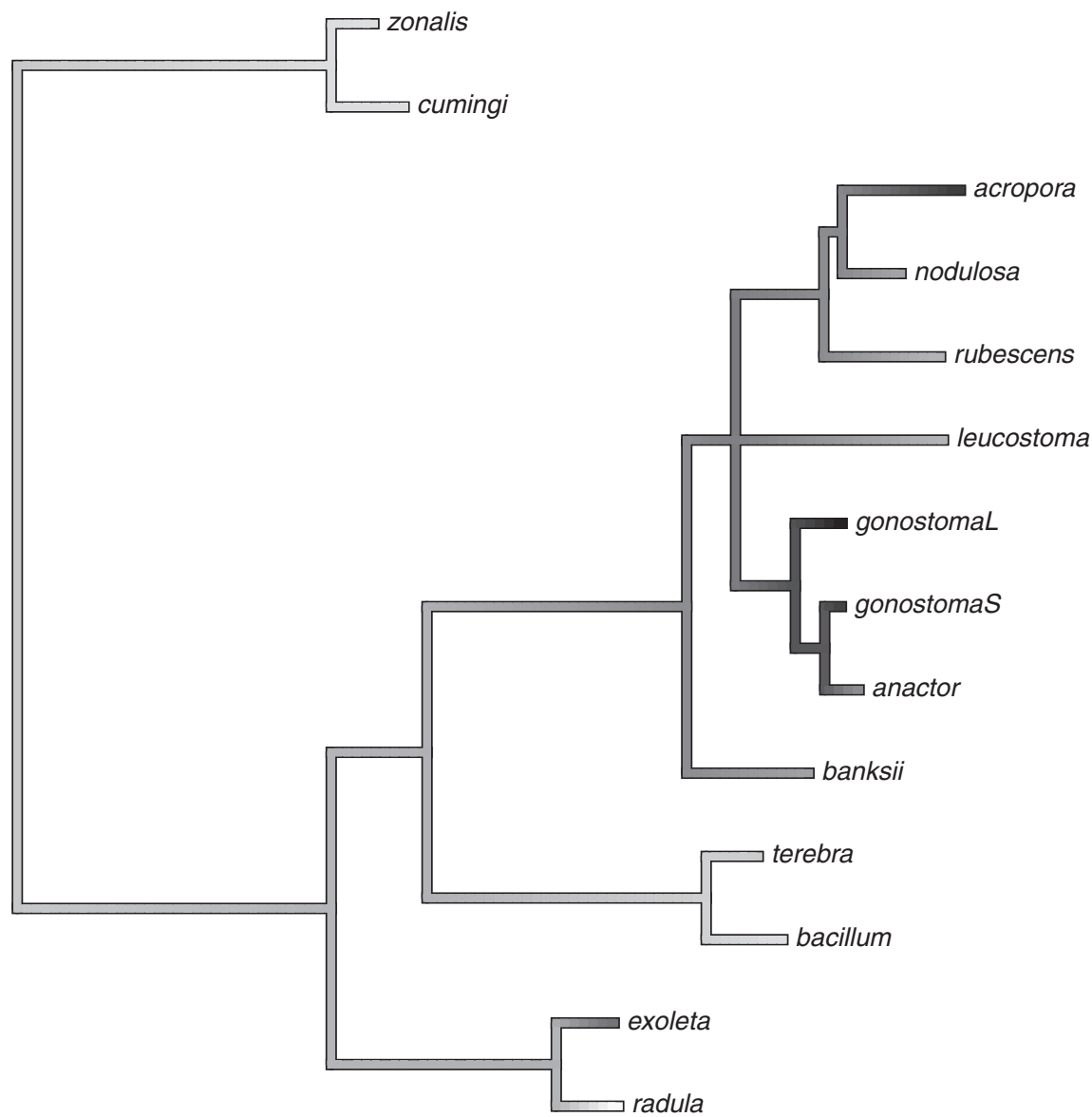

162

FIGURE 7 Ancestral state reconstruction with the trait value (grayscale) indicating protoconch diameter (micrometers), plotted onto a consolidated Bayesian phylogenetic tree. Our results indicate that the ancestral turritelline was likely planktotrophic. The " $\mathrm{L}$ " and " $\mathrm{S}$ " in $T$. gonostoma indicate whether the sequence was from Lieberman et al. (1993) or collected for this study, respectively. Length of the legend $(=0.33$ ) represents the length of the legend in units of branch length, which is expected mutations per site 
possible unrelated extinctions. The presumed difficulty of re-evolving planktotrophy also may bias the long-term accumulation of nonplanktotrophy in a clade, if the transition to nonplanktotrophy has no consequences for speciation (Duda \& Palumbi, 1999; Krug et al., 2015). There are two chief difficulties in assessing which of these macroevolutionary mechanisms was involved in the transition to larger protoconch sizes in WA turritellines. First, additional fossil protoconch data would need to be incorporated into a phylogenetic framework to distinguish between these evolutionary histories. Data from additional protoconchs, with both high-resolution stratigraphic data and confident species assignments, are obviously vital to assess the possibility of anagenetic selection for protoconch size increase. Efforts should be made to document protoconch sizes in the literature where possible, even maximum diameters from fragmented protoconchs, and collecting efforts should take special care not to neglect small apical fragments which may be rapidly screened for protoconchs using light microscopy. Second, the present status of turritelline systematics presents a further difficulty. It has been the operational assumption of many studies that long-distance dispersal events among turritellines are rare (e.g., Marwick, 1957). Both Lieberman et al. (1993) and the present study suggest that this assumption should be treated with some caution as there appear to be two clades in the neotropics, one of which is sister to a clade of species from South-East Asia. A global molecular phylogeny of Recent turritellines is needed to assess the validity of this assumption in regard to fossil species from the tropical Americas, and to aid in determining what morphological characters may be informative in assigning species to these clades.

Regardless of the evolutionary mechanisms involved in achieving nonplanktotrophy, decreased planktotrophy and diversity of turritellines after the closure of tropical American interoceanic seaways will likely have long-term consequences for the evolution of turritellines. Species-poor clades are more likely to be subject to stochastic extinction, and low-dispersal larvae may result in shifts in speciation rates, or, in punctuational systems, shifts in rates of morphospace exploration (Jablonski, 2017; Krug et al., 2015). Our phylogeny indicates that the two WA species examined are not closely related, and therefore, loss of either would substantially decrease the phylogenetic diversity (Faith, 1992) present in the region. The loss of planktotrophy has also been considered subject to Dollo's law, with limited opportunities for reversal due to the complex of characters necessary for larval feeding (Krug et al., 2015). This may not be the case as even direct-developing gastropods may pass through a veliger stage within the egg, without loss of associated characters (e.g., larval velum; Collin, 2004; Collin, Chaparro, Winkler, \& Veliz, 2007; Collin \& Cipriani, 2003; Collin \& Miglietta, 2008). If increased nonplanktotrophy decreases net diversification rates, selection toward higher parental investment in WA turritelline clades may have contributed to the overall decline in WA diversity as well (Krug et al., 2015). Investigating the evolution of WA and TEP turritelline protoconch size in a phylogenetic context may distinguish whether nonplanktotrophy has led to decreased net diversification rates in WA turritellines. If such a decrease is observed, then this shift in protoconch sizes may be evidence that WA turritellines represent two "dead clades walking" (Jablonski, 2002; Krug et al., 2015) following the Pliocene extinctions.

\section{ACKNOWLEDGMENTS}

We would like to thank A. Hendy, J. Santiago, L. Londono, and C. Jaramillo and the Smithsonian Tropical Research Institute for their assistance in facilitating collecting in Panama. We also thank Ricardo Perez for donating the Toyota vehicles used for fieldwork and the Dirección de Recursos Minerales for providing collecting permits. This is a contribution of the NSF Partnerships for International Research and Education Panama Canal Project (PCP-PIRE). We thank I. Lovette, A. Talaba, and B. Butcher for use of laboratory space and equipment for gene sequencing at the Cornell Laboratory of Ornithology. We also thank J. Slapcinsky (FLMNH), R. Portell (FLMNH), P. Callomon (ANSP), E. Strong (USNM), A. Baldinger (MCZ), L. Skibinski (PRI), and G. Dietl (PRI) for collections assistance. This work was funded by the Cornell Hunter R. Rawlings III Presidential Research Scholarship, the Office of Undergraduate Biology, Einhorn Discovery Grant, and the Cornell College of Arts and Sciences Undergraduate Research Grant.

\section{CONFLICT OF INTEREST}

None declared.

\section{AUTHOR CONTRIBUTION}

Stephanie Sang drafted the initial manuscript, performed molecular analyses, collected specimens, and performed analysis of both modern protoconchs and fossil protoconchs from Panama. Brendan Anderson led manuscript writing, performed Venezuelan protoconch analysis, and performed statistical analyses. Dana Friend assisted with identification and measurement of specimens and discussion of gastropod protoconch literature. Warren Allmon conceived of and supervised the project and edited the manuscript.

\section{DATA ACCESSIBILITY}

All molecular sequence data used in our analyses are available in GenBank, as outlined in Table 1.

\section{ORCID}

Stephanie Sang (iD https://orcid.org/0000-0001-7932-5032

\section{REFERENCES}

Aguilera, O., Lundberg, J., Birindelli, J., Sabaj Perez, M., Jaramillo, C., \& Sanchez-Villagra, M. R. (2013). Palaeontological evidence for the last temporal occurrence of the ancient western Amazonian river outflow 
into the Caribbean. PLoS One, 8, e76202. https://doi.org/10.1371/ journal.pone.0076202

Allmon, W. D. (1988). Ecology of Recent turritelline gastropods (Prosobranchia, Turritellidae): Current knowledge and paleontological implications. Palaios, 3, 259-284.

Allmon, W. D. (1992). Role of temperature and nutrients in extinction of turritelline gastropods in the northwestern Atlantic and northeastern Pacific. Palaeogeography, Palaeoclimatology, Palaeoecology, 92, 41-54. https://doi.org/10.1016/0031-0182(92)90134-q

Allmon, W. D. (2001). Nutrients, temperature, disturbance, and evolution: A model for the late Cenozoic marine record of the western Atlantic. Palaeogeography, Palaeoclimatology, Palaeoecology, 166, 9-26.

Allmon, W. D. (2011). Natural history of turritelline gastropods (Cerithiodea: Turritellidae): A status report. Malacologia, 54, 159202. https://doi.org/10.4002/040.054.0107

Allmon, W. D., Emslie, S. D., Jones, D. S., \& Morgan, G. S. (1996). Late Neogene oceanographic change along Florida's west coast: Evidence and mechanisms. The Journal of Geology, 104, 143-162.

Allmon, W. D., Rosenberg, G., Portell, R. W., \& Schindler, K. (1996). Diversity of Pliocene-Recent Mollusks in the Western Atlantic: Extinction, origination, and environmental change. In J. B. C. Jackson, A. F. Budd, \& A. G. Coates (Eds.), Evolution and environment in Tropical America (pp. 271-302). Chicago, IL: University of Chicago Press.

Anderson, B. M., Hendy, A., Johnson, E. H., \& Allmon, W. D. (2017). Paleoecology and paleoenvironmental implications of turritelline gastropod-dominated assemblages from the Gatun Formation (Upper Miocene) of Panama. Palaeogeography, Palaeoclimatology, Palaeoecology, 470, 132-146. https://doi.org/10.1016/j.palaeo. 2017.01.026

Beu, A. G. (2001). Gradual Miocene to Pleistocene uplift of the Central American Isthmus: Evidence from tropical American Tonnoidean gastropods. Journal of Paleontology, 75, 706-720.

Bhaud, M. (1993). Relationship between larval type and geographic range in marine species-complementary observations on gastropods. Oceanologica Acta, 16, 191-198.

Bruguière, J. G. (1792). Encyclopédie méthodique. In P. M. Bruguière (Eds.), Histoire naturelle des vers. Tome premier: Chez Panckoucke.

Coates, A. G., Aubry, M.-P., Berggren, W. A., Collins, L. S., \& Kunk, M. (2003). Early Neogene history of the Central American arc from Bocas del Toro, western Panama. Geological Society of America Bulletin, 115, 271-287.

Coates, A. G., Collins, L. S., Aubry, M.-P., \& Berggren, W. A. (2004). The geology of the Darien, Panama, and the late Miocene-Pliocene collision of the Panama arc with northwestern South America. GSA Bulletin, 116, 1327-1344.

Colgan, D. J., McLauchlan, A., Wilson, G. D. F., Livingston, S. L., Edgecombe, G. D., Macaranas, J., ... Gray, M. R. (1998). Histone H3: and $\mathrm{U} 2$ snRNA DNA sequences and arthropod molecular evolution. Australian Journal of Zoology, 46, 419-457.

Collin, R. (2004). Phylogenetic effects, the loss of complex characters, and the evolution of development in calyptraeid gastropods. Evolution, 58, 1488-1502. https://doi.org/10.1554/03-038

Collin, R., Chaparro, O. R., Winkler, F., \& Veliz, D. (2007). Molecular phylogenetic and embryological evidence that feeding larvae have been reacquired in a marine gastropod. Biological Bulletin, 212, 83-92. https://doi.org/10.2307/25066586

Collin, R., \& Cipriani, R. (2003). Dollo's law and the re-evolution of shell coiling. Proceedings of the Royal Society B: Biological Sciences, 270, 2551-2555.

Collin, R., \& Miglietta, M. P. (2008). Reversing opinions on Dollo's Law. Trends in Ecology and Evolution, 23, 602-609.

Collins, L. (1996). Environmental changes in Caribbean shallow waters relative to the closing tropical American seaway. In J. B.C. Jackson,
A. F. Budd \& A. G Coates (Eds.), Evolution and Environment in Tropical America. Chicago, IL: University of Chicago Press.

Conrad, T. A., (1857). Descriptions of Cretaceous and Tertiary fossils. Albany, NY: C. Wendell, printer.

Copenhaver, M. D., \& Holland, B. (1988). Computation of the distribution of the maximum studentized range statistic with application to multiple significance testing of simple effects. Journal of Statistical Computation and Simulation, 30, 1-15. https://doi. org/10.1080/00949658808811082

Coppard, S. E., \& Lessios, H. (2017). Phylogeography of the sand dollar genus Encope: Implications regarding the Central American Isthmus and rates of molecular evolution. Scientific Reports, 7, 11520. https:// doi.org/10.1038/s41598-017-11875-w

Crampton, J. S., Cooper, R. A., Beu, A. G., Foote, M., \& Marshall, B. A. (2010). Biotic influences on species duration: Interactions between traits in marine molluscs. Paleobiology, 36, 204-223. https://doi. org/10.1666/09010.1

Crisp, D., \& Spencer Davies, P. (1976). The role of the pelagic larva. Perspectives in Experimental Biology, 1, 145-155. https://doi. org/10.1016/b978-0-08-018767-9.50017-2

Cronin, T. M., \& H. J. Dowsett (Eds.) (1996). Biotic and oceanographic response to the Pliocene closing of the Central American Isthmus. Chicago, IL: University of Chicago Press.

Dall, W. H. (1889). Reports on the results of dredging, under the supervision of Alexander Agassiz, in the Gulf of Mexico (1877-78) and in the Caribbean Sea (1879-80), by the U.S. Coast Survey Steamer "Blake", Lieut.-Commander C.D. Sigsbee, U.S.N., and Commander J.R. Bartlett, U.S.N., commanding. XXIX. Report on the Mollusca. Part 2, Gastropoda and Scaphopoda. Harvard College, Cambridge: Bulletin of the Museum of Comparative Zoölogy 18: 1-492, pls. 10-40.

Deshayes, G. P., \& Milne-Edwards, H. (1843). Histoire Naturelle des Animaux sans Vertèbres, présentant les caractères généraux et particuliers de ces animaux, leur distribution, leurs classes, leurs familles, leurs genres, et la citation des principales espèces qui s'y rapportent, par J.B.P.A. de Lamarck. Deuxième édition, Tome neuvième. Histoire des Mollusques (pp. 728). Paris, France: Jean-Baptiste Baillière.

Duda, T. F., \& Palumbi, S. R. (1999). Developmental shifts and species selection in gastropods. Proceedings of the National Academy of Sciences of the United States of America, 96, 10272-10277. https://doi. org/10.1073/pnas.96.18.10272

Orbigny A.D. d'. (1835-1847). Voyage dans l'Amérique méridionale [...] exécuté pendant les années 1826, 1827, 1828, 1829, 1830, 1831, 1832 et 1833. Tome 5, Partie 3, Mollusques. pp. i-xliii; 1-758; 85 plates [pp. 1-104, pls 1-7, 10, 12 (1835); 105-184, pls 8-9, 11, 13-23, 25-28, 31 (1836); pls 24, 29-30, 32-35, 37-43 (1837); 185-376, pls 44, 47-52, 55 (1838); pls 56-59, 64-65 (1839); 377-472, pls 53-54, 60-63, 66-74, 79 (1841); 473-488, pls 75-76, 80, 83, 85 (1842); 489-528 (1846); 529600 (1845); 601-728 (1846); 78-79, 81-82 (1847).

Faith, D. P. (1992). Conservation evaluation and phylogenetic diversity. Biological Conservation, 61, 1-10. https://doi.org/10.1016/ 0006-3207(92)91201-3

Farell, E. M., \& Alexandre, G. (2012). Bovine serum albumin further enhances the effects of organic solvents on increased yield of polymerase chain reaction of GC-rich templates. BMC Research Notes, 5, 257.

Fortunato, H. (2002). Reproduction and larval development of the Strombina-group and related gastropods: Testing the use of the larval shell for inference of development in fossil species. (Buccinoidea: Columbellidae). Bollettino Malacologico, 46, 111-126.

Fortunato, H. (2004). Reproductive strategies in gastropods across the Panama seaway. Invertebrate Reproduction and Development, 46, 139148. https://doi.org/10.1080/07924259.2004.9652617

Hammer, Ø., Harper, D. A. T., \& Ryan, P. D. (2001). PAST: Paleontological Statistics Software Package for education and data analysis. Palaeontologia Electronica, 4, 9. 
Hansen, T. A. (1978). Larval dispersal and species longevity in Lower Tertiary gastropods. Science, 199, 885-887. https://doi.org/10.1126/ science.199.4331.885

Hays, P. E., Pisias, N., \& Roelofs, A. (1989). Paleoceanography of the eastern equatorial Pacific during the Pliocene: A high-resolution radiolarian study. Paleoceanography and Paleoclimatology, 4, 57-73. https:// doi.org/10.1029/pa004i001p00057

Hendy, A. J. W. (2013). Spatial and stratigraphic variation of marine paleoenvironments in the Middle-Upper Miocene Gatun Formation, Isthmus of Panama. Palaios, 28, 210-227. https://doi.org/10.2110/ palo.2012.p12-024r

Hodson, W. E. H. (1926). Observations on the biology of Tylenchus dipsaci (Kuhn) Bastian, and on the occurrence of biologic strains of the nematode. Annals of Applied Biology, 13(2), 219-228.

Hickman, C. S. (2001). Evolution and development of gastropod larval shell morphology: Experimental evidence for mechanical defense and repair. Evolution and Development, 3, 18-23. https://doi. org/10.1046/j.1525-142x.2001.01003.x

Jablonski, D. (1987). Heritability at the species level: Analysis of geographic ranges of Cretaceous mollusks. Science, 238, 360-363. https://doi.org/10.1126/science.238.4825.360

Jablonski, D. (2002). Survival without recovery after mass extinctions. Proceedings of the National Academy of Sciences of the United States of America, 99, 8139-8144. https://doi.org/10.1073/pnas.102163299

Jablonski, D. (2017). Approaches to macroevolution: 2. Sorting of variation, some overarching issues, and general conclusions. Evolutionary Biology, 44, 451-475.

Jablonski, D., \& R. A. Lutz (Eds.) (1980). Molluscan larval shell morphology: Ecological and paleontological applications. New York, NY: Plenum.

Jablonski, D., \& Lutz, R. A. (1983). Larval ecology of marine benthic invertebrates: Paleobiological implications. Biological Reviews, 58, 21-89. https://doi.org/10.1111/j.1469-185x.1983.tb00380.x

Jablonski, D., \& Valentine, J. W. (1990). From regional to total geographic ranges: Testing the relationship in recent bivalves. Paleobiology, 16, 126-142. https://doi.org/10.1017/s0094837300009842

Jackson, J. B., \& Budd, A. F. (1996). Evolution and environment: Introduction and overview. In J. B. C Jackson, A. F. Budd \& A. G. Coates (Ed.), Evolution and environment in Tropical America (pp. 1-20). Chicago, IL: University of Chicago Press.

Jackson, J. B., \& Fortunato, H. (1996). Do Differences in productivity affect molluscan faunas? A preliminary test using Tropical Eastern Pacific Strombinid Gastropods. The Paleontological Society Special Publications, 8, 191-191.

Jackson, J. B. C., \& Johnson, K. G. (2000). Life in the last few million years. Paleobiology, 26, 221-235. https://doi.org/10.1017/ s0094837300026944

Jackson, J. B. C., Jung, P., \& Fortunato, H. (1996). Paciphilia revisited: Transisthmian evolution of the Strombina group (Gastropoda: Columbellidae). In J. B. C. Jackson, A. F. Budd, \& A. Coates (Eds.), Evolution and environment in Tropical America (pp. 234-270). Chicago, IL: University of Chicago Press.

Jackson, J. B. C., \& O'Dea, A. (2013). Timing of the oceanographic and biological isolation of the Caribbean Sea from the Tropical Eastern Pacific Ocean. Bulletin of Marine Science, 89, 779-800.

Johnson, E. H., Anderson, B. M., \& Allmon, W. D. (2017). What can we learn from all those pieces? Obtaining data on drilling predation from fragmented high-spired gastropod shells. Palaios, 32, 271-277. https://doi.org/10.2110/palo.2016.088

Jones, D. S., \& Allmon, W. D. (1995). Records of upwelling, seasonality and growth in stable-isotope profiles of Pliocene mollusk shells from Florida. Lethaia, 28, 61-74.

Jordan, D. S. (1908). The law of geminate species. American Naturalist, $42,73-80$.

Katoh, K., \& Standley, D. M. (2013). MAFFT multiple sequence alignment software version 7: Improvements in performance and usability. Molecular Biology and Evolution, 30, 772-780. https://doi. org/10.1093/molbev/mst010

Keen, A. M. (1971). Sea shells of tropical west America: Marine mollusks from Baja California to Peru (2nd ed.). Stanford, CA: Stanford University Press.

Keigwin, L. (1982). Isotopic paleoceanography of the Caribbean and East Pacific: Role of Panama uplift in late Neogene time. Science, 217, 350-353.

Kiener, L.C. (1838). Spécies général et iconographie des coquilles vivantes. Vol. 10. Famille des Turbinacées. Genre Turritelle (Turritella, Lam.), pp. 1-46, pl. 1-14 [pp. 1-46 (1844), pl. 1-3, 5, 7-14 (1843), 4, 6 (1844)]; Vol. 4; pp. 5-6

Krug, P. J., Vendetti, J. E., Ellingson, R. A., Trowbridge, C. D., Hirano, Y. M., Trathen, D. Y., ... Valdés, Á. A. (2015). Species selection favors dispersive life histories in sea slugs, but higher per-offspring investment drives shifts to short-lived larvae. Systematic Biology, 64, 983-999.

Lanfear, R., Calcott, B., Ho, S. Y., \& Guindon, S. (2012). PartitionFinder: Combined selection of partitioning schemes and substitution models for phylogenetic analyses. Molecular Biology and Evolution, 29, 1695-1701.

Leigh, E. G., O'Dea, A., \& Vermeij, G. J. (2014). Historical biogeography of the Isthmus of Panama. Biological Reviews of the Cambridge Philosophical Society, 89, 148-172.

Lessios, H. (1990). Adaptation and phylogeny as determinants of egg size in echinoderms from the two sides of the Isthmus of Panama. American Naturalist, 135, 1-13.

Lessios, H. (2008). The Great American Schism: Divergence of marine organisms after the rise of the Central American Isthmus. Annual Review of Ecology, Evolution, and Systematics, 39, 63-91.

Lieberman, B. S., Allmon, W. D., \& Eldredge, N. (1993). Levels of selection and macroevolutionary patterns in the turritellid gastropods. Paleobiology, 19, 205-215.

Lima, G. M., \& Lutz, R. A. (1990). The relationship of larval shell morphology to mode of development in marine Prosobranch gastropods. Journal of the Marine Biological Association of the United Kingdom, 70, 611-637.

Linnaeus, C. (1758). Systema naturae per regna tria naturae, secundum classes, ordines, genera, species, cum characteribus, differentiis, synonymis, locis (pp. 824). Holmiae: Editio decima, reformata. Laurentius Salvius.

Maddison, W. P., \& Maddison, D. R. (2015). Mesquite: A modular system for evolutionary analysis. Version 3.03. pp.

Maier-Reimer, E., Mikolajewicz, U., \& Crowley, T. (1990). Ocean general circulation model sensitivity experiment with an Open Central American Isthmus. Paleoceanography, 5, 349-366.

Marko, P. B., \& Moran, A. (2002). Correlated evolutionary divergence of egg size and a mitochondrial protein across the Isthmus of Panama. Evolution, 56, 1303-1309.

Marko, P. B., \& Moran, A. L. (2009). Out of sight, out of mind: High cryptic diversity obscures the identities and histories of geminate species in the marine bivalve subgenus Acar. Journal of Biogeography, 36, 1861-1880.

Marshall, D. J., \& Keough, M. J. (2007). The evolutionary ecology of offspring size in marine invertebrates. Advances in Marine Biology., 53, 1-60.

Marshall, D., McAlister, J. S., \& Retizel, A. M. (2018). Evolutionary ecology of parental investment and larval diversity. In T. J. Carrier, A. M. Reitzel, \& A. Heyland (Eds.), Evolutionary ecology of marine invertebrate larvae (pp. 34-49). Oxford, UK: Oxford University Press.

Marwick, J. (1957). Generic revision of the Turritellidae. Journal of Molluscan Studies, 32, 144-166.

McLEAN, J. H. (1970). New species of panamic gastropods. Veliger, 12(3), 310-315.

Mileikovsky, S. (1971). Types of larval development in marine bottom invertebrates, their distribution and ecological significance: A re-evaluation. Marine Biology, 10, 193-213. 
Miller, M. A., Pfeiffer, W., \& Schwartz, T. (2010). Creating the CIPRES Science Gateway for inference of large phylogenetic trees. In Gateway Computing Environments Workshop (GCE), 2010 (pp. 1-8). IEEE.

Miura, O., Frankel, V., \& Torchin, M. E. (2011). Different developmental strategies in geminate mud snails, Cerithideopsis californica and $C$. pliculosa, across the Isthmus of Panama. Journal of Molluscan Studies, 77, 255-258.

Miura, O., Kuris, A. M., Torchin, M. E., Hechinger, R. F., Dunham, E. J., \& Chiba, S. (2005). Molecular-genetic analyses reveal cryptic species of trematodes in the intertidal gastropod, Batillaria cumingi (Crosse). International journal for parasitology, 35(7), 793-801.

Miura, O., Torchin, M.E., Kuris, A. M., Hechinger, R. F., \& Chiba, S. (2006). Introduced cryptic species of parasites exhibit different invasion pathways. Proceedings of the National Academy of Sciences, 103, 19818-19823.

Molnar, P. (2008). Closing of the Central American Seaway and the Ice Age: A critical review. Paleoceanography 23. https://doi. org/10.1029/2007pa001574

Moran, A. L. (2004). Egg size evolution in tropical American arcid bivalves: The comparative method and the fossil record. Evolution, 58, 2718-2733. https://doi.org/10.1554/04-142

Moran, A. L., \& McAlister, J. S. (2009). Egg size as a life history character of marine invertebrates: Is it all it's cracked up to be? The Biological Bulletin, 216, 226-242. https://doi.org/10.1086/ bblv216n3p226

O'Dea, A., \& Collins, L. S. (2013). Environmental, ecological, and evolutionary changes in seas across the Isthmus of Panama. Bulletin of Marine Science, 89, 769-777. https://doi.org/10.5343/bms.2013.1018

O'Dea, A., Jackson, J. B., Fortunato, H., Smith, J. T., D'Croz, L., Johnson, K. G., \& Todd, J. A. (2007). Environmental change preceded Caribbean extinction by 2 million years. Proceedings of the National Academy of Sciences of the United States of America, 104, 5501-5506.

O'Dea, A., Lessios, H. A., Coates, A., Eytan, R. I., Collins, L. S., Cione, A. L., ... Jackson, J. B. (2018). Formation of the Isthmus of Panama: Response to Jaramillo et al. Science Advances, 2, e1600883. https:// doi.org/10.1126/sciadv.1600883

O'Dea, A., Lessios, H. A., Coates, A. G., Eytan, R. I., Restrepo-Moreno, S. A., Cione, A. L., ... Jackson, J. B. (2016). Formation of the Isthmus of Panama. Science Advance, 2, e1600883. https://doi.org/10.1126/ sciadv.1600883

Parsons, K. E. (1997). Role of dispersal ability in the phenotypic differentiation and plasticity of two marine gastropods. Oecologia, 110, 461-471. https://doi.org/10.1007/s004420050181

Pérez-Consuegra, N., Parra, M., Jaramillo, C., Silvestro, D., Echeverri, S., Montes, C., ... Escobar, J. (2018). Provenance analysis of the Pliocene Ware Formation in the Guajira Peninsula, northern Colombia: Paleodrainage implications. Journal of South American Earth Sciences, 81, 66-77.

Rambaut, A. (2016). FigTree v1.4.3: Tree Figure Drawing Tool. pp.

Rambaut, A., \& Suchard, M. A. (2014). Tracer vol 1.6. pp.

Revell, L. J. (2012). phytools: An R package for phylogenetic comparative biology (and other things). Methods in Ecology and Evolution, 3, 217-223.

Robertson, R. (1971). Scanning electron microscopy of planktonic larval marine shells. Veliger, 14, 1-12.

Ronquist, F., \& Huelsenbeck, J. P. (2003). MrBayes 3: Bayesian phylogenetic inference under mixed models. Bioinformatics, 19, 1572-1574.

Scheltema, R. S. (1971). Larval dispersal as a means of genetic exchange between geographically separated populations of shallow-water benthic marine gastropods. Biological Bulletin, 140, 284-322. https:// doi.org/10.2307/1540075

Scheltema, R. (1978). On the relationship between dispersal of pelagic veliger larvae and the evolution of marine prosobranch gastropods. Marine organisms: genetics, ecology and evolution (pp. 303-322). New York, NY: Plenum Press.

Schneider, C. A., Rasband, W. S., \& Eliceiri, K. W. (2012). NIH Image to Image J: 25 years of image analysis. Nature Methods, 9(7), 671-675.

Shuto, T. (1974). Larval ecology of prosobranch gastropods and its bearing on biogeography and paleontology. Lethaia, 7, 239-256. https:// doi.org/10.1111/j.1502-3931.1974.tb00899.x

Simon, C., Franke, A., \& Martin, A. (1991). The polymerase chain reaction: DNA extraction and amplification. In G. M. Hewitt, A. W. B. Johnston, \& J. P. W. Young (Eds.), Molecular techniques in taxonomy, (Vol. 57). Berlin, Heidelberg: Springer.

Smith, J. T., \& Jackson, J. B. C. (2009). Ecology of extreme faunal turnover of tropical American scallops. Paleobiology, 35, 77-93. https:// doi.org/10.1666/07054.1

Stöver, B. C., \& Müller, K. F. (2010). TreeGraph 2: Combining and visualizing evidence from different phylogenetic analyses. BMC Bioinformatics, 11, 7. https://doi.org/10.1186/1471-2105-11-7

Strathmann, R. R. (1978). The evolution and loss of feeding larval stages of marine invertebrates. Evolution, 32, 894-906. https://doi. org/10.1111/j.1558-5646.1978.tb04642.x

Strong, E. E., Colgan, D. J., Healy, J. M., Lydeard, C., Ponder, W. F., \& Glaubrecht, M. (2011). Phylogeny of the gastropod superfamily Cerithioidea using morphology and molecules. Zoological Journal of the Linnean Society, 162, 43-89.

Swofford, D. L. (2002). PAUP* Phylogenetic Analysis Using Parsimony (*and Other Methods). Version 4. Sunderland, MA: Sinauer Associates.

Thorson, G. (1950). Reproductive and larval ecology of marine bottom invertebrates. Biological Reviews, 25, 1-45. https://doi.org/10.1111/ j.1469-185x.1950.tb00585.x

Todd, J. A., Jackson, J. B., Johnson, K. G., Fortunato, H. M., Heitz, A., Alvarez, M., \& Jung, P. (2002). The ecology of extinction: Molluscan feeding and faunal turnover in the Caribbean Neogene. Proceedings of the Royal Society of London. Series B: Biological Sciences, 269, 571577. https://doi.org/10.1098/rspb.2001.1923

Todd, J. A., \& Johnson, K. G. (2013). Dissecting a marine snail species radiation (Conoidea: Turridae: Polystira) over 12 million years in the southwestern Caribbean. Bulletin of Marine Science, 89, 877-904. https://doi.org/10.5343/bms.2012.1083

Vaidya, G., Lohman, D. J., \& Meier, R. (2011). SequenceMatrix: Concatenation software for the fast assembly of multi-gene datasets with character set and codon information. Cladistics, 27, 171-180.

Vance, R. R. (1973). On reproductive strategies in marine benthic invertebrates. American Naturalis, 107, 339-352. https://doi. org $/ 10.1086 / 282838$

Vendetti, J. E. (2007). Protoconch comparative morphology in extinct and extant buccinid gastropods and its utility in paleobiogeography, systematics, and inferring larval mode. Malacologist, 48, 1-5.

Vermeij, G. J. (1982). Gastropod shell form, breakage, and repair in relation to predation by the crab Calappa. Malacologia, 23, 1-12.

Wehrtmann, I., \& Albornoz, L. (2002). Evidence of different reproductive traits in the transisthmian sister species, Alpheus saxidomus and A. simus (Decapoda, Caridea, Alpheidae): Description of the first postembryonic stage. Marine Biology, 140, 605-612. https://doi. org/10.1007/s00227-001-0733-1

Woodring, W. P. (1957). Geology and paleontology of canal zone and adjoining parts of Panama. Panama, FL: United States Geological Survey Professional.

Woide, D., Zink, A., \& Thalhammer, S. (2010). Technical note: PCR analysis of minimum target amount of ancient DNA. American Journal of Physical Anthropology, 142, 321-327. https://doi.org/10.1002/ ajpa. 21268

Zou, S., Li, Q., \& Kong, L. (2011). Additional gene data and increased sampling give new insights into the phylogenetic relationships of 
Neogastropoda, within the caenogastropod phylogenetic framework. Molecular Phylogenetics and Evolution, 61, 425-435.

\section{SUPPORTING INFORMATION}

Additional supporting information may be found online in the Supporting Information section at the end of the article.
How to cite this article: Sang S, Friend DS, Allmon WD, Anderson BM. Protoconch enlargement in Western Atlantic turritelline gastropod species following the closure of the Central American Seaway. Ecol Evol. 2019;9:5309-5323. https://doi.org/10.1002/ece3.5120 